\title{
Development of adversity quotient based geometry learning model for prospective teachers
}

\author{
Sudarman Bennu ${ }^{1}$, Akina ${ }^{2}$ \\ ${ }^{1,2}$ Universitas Tadulako, Jl. Soekarno Hatta Km.9 Palu, Indonesia
}

\begin{tabular}{l}
\hline A R T I C L E I N F O \\
Original Article \\
DOI: 10.18860/ijtlm.v2i2.9352 \\
\hline Keywords: \\
Teaching Model, Mathematics, \\
Geometry Learning, Adversity \\
Quotient
\end{tabular}

\begin{abstract}
A B S T R A C T
The objective of this research is to develop the adversity quotientbased and media-assisted model of mathematics teaching. The stages follow Plomp Model that involves (1) preliminary study, (2) designing (planning), (3) realization/ construction, (4) test, evaluation and revision, (5) implementation. Stages 1 through 3 were held in 2017, stages 4 and 5 completed in 2018 and 2019. Through the preliminary study, designing, and realization/construction, the researchers were able to construct the model in five components: syntax, social system, reaction principles, supporting system, and instructional and nurturing effect. The syntax of this model covers: introduction of learning objectives, motivating, the presentation of prerequisite material and the discussion structured task, student categorization based on adversity quotient, group discussion, group presentation, concluding the discussion, evaluation, and assigning structuredtasks individually and in groups.
\end{abstract}

(C) 2019 IJTLM. All rights reserved.

*Corresponding author.

E-mail: sudarmanbennu@gmail.com

How to cite: Bennu, S., \& Akina. (2019). Development of adversity quotient based geometry learning model for prospective teachers. International Journal on Teaching and Learning Mathematics, 2(2), 6066.

\section{INTRODUCTION}

The research proceeded by need analysis and preliminary study that resulted in the Adversity Quotient (AQ) of the students of Primary School Teacher Education study program of Tadulako University in 2010/2011 and 2015/2016. The AQ of PGSD Tadulako University students, both of Class 2010/2011 and Class 2015/2016, was dominantly in the camper category, $79.17 \%$ in Class 2010/2011 and 78.95\% in Class 2015/2016. The condition of the two classes reflected the situation of all students of PGSD Tadulako University. So that, it can be stated that the AQ category of PGSD Tadulako University students was camper or in a moderate category.

Students with quitter category in Class 2010/2011 were $16.67 \%$ decreased $1.84 \%$ in the year of 2015/2016 into $14.83 \%$, and students with camper category in Class 2010/2011 were $79.17 \%$ decreased $0.22 \%$ in the year of $2015 / 2016$ into $78,95 \%$. While students with climber category in Class 2010/2011 were $79.17 \%$ decreased by $0.22 \%$ in the year of $2015 / 2016$ into $78,95 \%$. While students with climber category in Class 2010/2011 were $4.17 \%$ increased by $2.05 \%$ in the year of 2015/2016 into 6.22\%. From the class 2010/2011 to class 2015/2016, the AQ of PGSD Tadulako University students doesn't have a significant increase.

As a study program that produces primary school teachers, PGSD Tadulako University teaches its students mathematical courses. One of them is Geometry Teaching. The students' grades in the last three years represented by classes 2012/2013, 2013/2014, and 2014/2015. The 
students of Tadulako University Classes 2012/2013 and 2013/2014 use grading system of A, B,

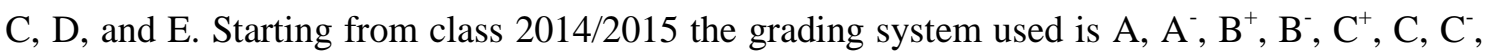
D, E. The PGSD students of Tadulako University classes 2012/2013/2013/2014, 2014/2015, who got A were $9,09 \%, 8,8 \%$, and $7,76 \%$ respectively. The fact shows that very few of the students got A. So that, it can be said that in general, the PGSD students' grades were low, B+, $\mathrm{B}, \mathrm{B}-, \mathrm{C}+, \mathrm{C}, \mathrm{C}-, \mathrm{D}$, and $\mathrm{E}$. The result of the researcher shows that the cause of this phenomenon is that the implementation of a conventional method of teaching that not equipped with learning media.

The nowadays global era requires teachers not only with good mastery of course content but also high AQ (Bautista, 2015; Cando \& Villacastin, 2014; Marashi \& Rashidian, 2018; Parvathy \& Praseeda, 2014). Teachers with high AQ can overcome problems they encounter, and even they can change threats into an opportunity (Stoltz, 1997, 2000). Teachers who sincerely dedicate themselves to rural areas without complaint can be developed through the implementation of AQ-based with the media-assisted model of teaching and learning devices.

There are some researches relate to AQ and its relation to learning achievement. D'sousa (2006) investigated AQ of secondary school students in relation to their school performace and the school climate. Furthermore, several studies revealed students' thought process based on AQ (Bennu, 2011, 2012, 2015). (Hema and Gupta (2015) reported that AQ is not influenced by gender, stream of education and family factors, rather it was seen to be influenced by the type of schools. The problem is that there has not been an AQ-based and media-assisted model of teaching and learning devices. For that purpose, this research is held to develop an AQ-based with media-assisted model of teaching and learning devices to increase the AQ and achievement of the students in the course of geometry teaching.

\section{METHOD}

This study is a research and development, held at the Primary School Teacher Education Study Program of Universitas Tadulako. The subjects were the students of class 2018/2019. The development model applied is the one suggested by Plomp (1997) covering five stages: (1) preliminary study stage, (2) designing stage, (3) realization/construction stage, (4) test, evaluation and revision stage, and (5) implementation stage. The preliminary study, designing, and realization or construction stages were complete in 2017. The next stage, test, evaluation, and revision stage were done in 2018. The last stage, implementation, was held in 2019. This research and development follow the stages, as illustrated in the flow chart in Figure 1. 
International Journal on Teaching and Learning Mathematics

2019, Vol. 2, No. 2, pp. 60-66

P-ISSN: 2621-2188, E-ISSN: 2621-2196

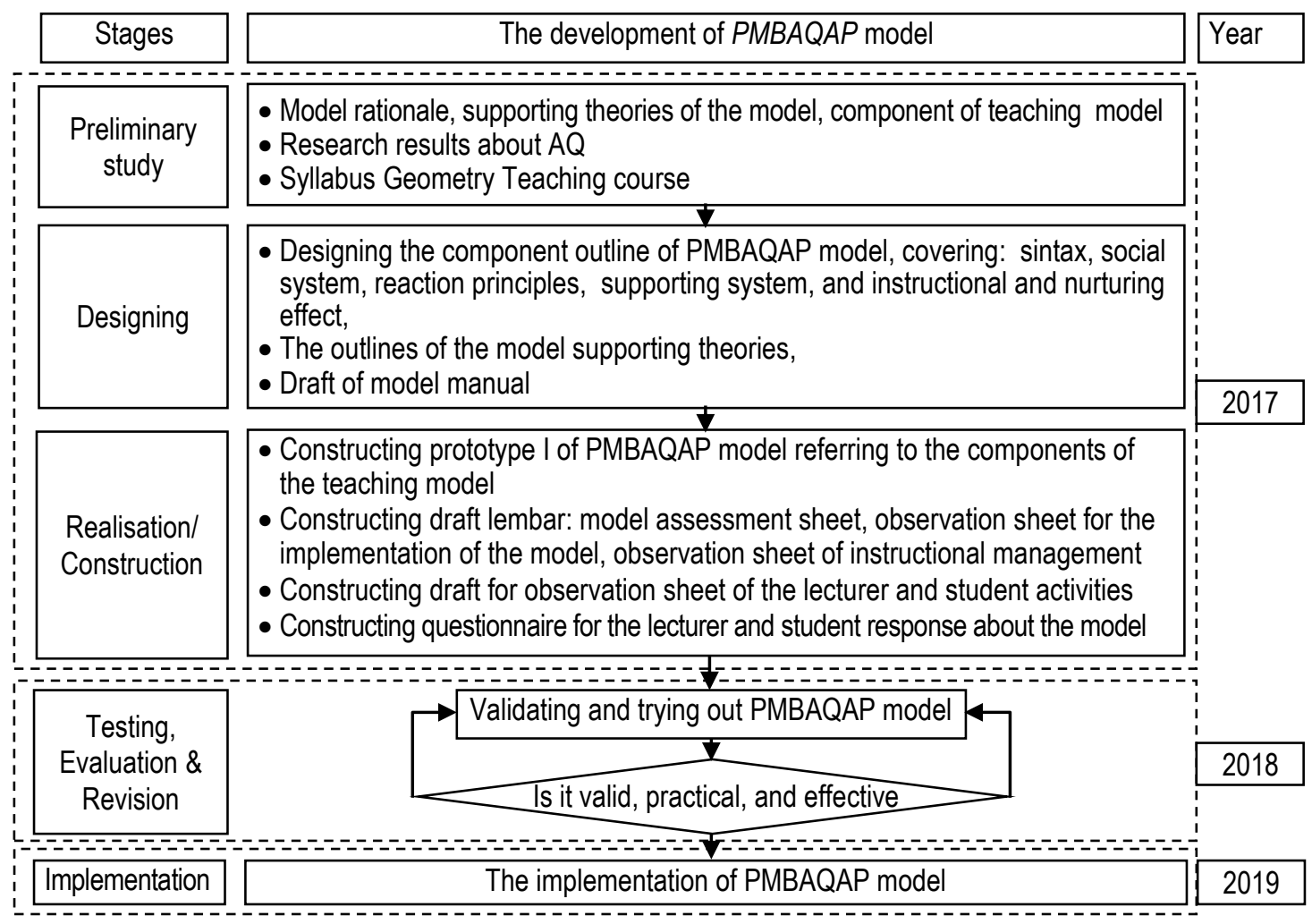

Figure 1. Flow chart of research implementation

\section{RESULTS AND DISCUSSION}

The research result reported in this article is limited to the result of the first year, namely the result in a stage of preliminary study, designing, and realization/construction. The product of the preliminary study is the rationality of the necessity for the development of the PMBAQAP model. The preliminary study can found that most PGSD students of Tadulako University have a camper or moderate category of AQ. Their grades in the course of Geometry Teaching were low; B+, B, B-, C+, C, C-, D, E. This evidence reflects that the quality of primary school teachers that are graduated by PGSD Tadulako University will be low. These teachers have low professional competence and AQ. The circumstance cannot be neglected, for teachers with low AQ will produce graduates with low AQ as well.

Professional teachers with high AQ can be produced through a teaching model that pays attention to the students' AQ. Up to now, such a model of teaching has not been invented. That is why the development of the AQ-based model of teaching is necessary. Another finding at the preliminary study is that some learning theories support the PMBAQ model, among them, are constructivism learning theory, cognitive learning theory, and cooperative learning theory with its various types, and adversity quotient.

PMBAQAP model gives opportunity to the students to construct their knowledge themselves. Lecturers only play role of advisors and facilitators. Such model of learning goes with the constructivism theory of learning. Constructivism learning gives opportunity to the learners to construct their knowledge themselves (Akpan \& Beard, 2016; Kroll \& Laboskey, 1996; Noorloos et al., 2017; Vrasidas, 2000; Wheatley, 1991). In PMBAQAP model, student thinks complex, actively learns, learns through social interaction and through self-experience. PMBAQAP model is supported by cognitive theory of learning. 
In PMBAQAP model, student learns involving complex process of thinking that involves basic psychology principles, that are, active learning, learns through social interaction and through self-experience. PMBAQAP model is supported by cognitive theory of learning. Learning is not merely a relationship between stimulus and response (Kamboj et al., 2018). It also involves a complex process of thinking. Learning involves the basic principles of psychology, namely active learning, learns through social interaction and through selfexperience. Then, in PMBAQAP model, students are set in groups by considering their AQ category and their mathematical capability. Each group consists of 3 to 6 students, that is why PMBAQAP model is supported by cooperative theory of learning.

The product in designing, and realization or construction stages is components of PMBAQAP model consists of: syntax, social system, reaction principles, supporting system, and instructional effect and its nurturing effect. The components are similar to the components of teaching model introduced by Joyce et al. (2009) namely: syntax, social system, reaction principles, supporting system, and instructional effect and its nurturants.

Generally the syntax of PMBAQAP model consists of three phases: introduction, core, and closing. The activities in introduction phase cover: (a) opening the lesson, (b) greeting and praying, (c) attendance check, (d) introducing learning objectives, (e) motivating, (f) informing prerequisite materials, (g) discussing structured tasks, (h) grouping students based on their AQ categories. The activities in core phase cover: (a) the distribution of worksheets, (e) group discussion, (f) group presentation, ( $\mathrm{g}$ ) conclusion of discussion, (h) evaluation, and (i). The activity in closing phase assigning structured tasks individually and in groups.

The situation or the atmosphere and the norm applied in a model of teaching is called social system (Boa et al., 2018; Gidena \& Gebeyehu, 2017; Pea, 2004; Wenger, 2010). Prominent social system in PMBAQAP model is the lecturer's role as advisor and facilitator in giving information and directing to set groups and discussion. Interaction PMBAQAP model of teaching is the combination of one-way interaction, two-way interaction, and multi-way interaction. One-way interaction exists when the lecturer gives information to the students, while in the time of knowledge construction by the students; two-way interaction dominantly exists between lecturer and students (Kristanti et al., 2018). When discussing the result of worksheets, multi-way interaction exists: from lecturer to students, from students to lecturer, and from students to students.

When the teaching and learning process runs, there are activities pattern that reflect how lecturer views and treats the students, including the way lecturer or teacher responds to his students. The activity pattern of teacher or lecturer in treating and responding to his students is called reaction principle (Boa et al., 2018; Blackmore, 2010; Gidena \& Gebeyehu, 2017). Some behaviors that are expected to perform by the lecturer in carrying out the syntax of PMBAQAP model are (a) create conducive atmosphere in introducing the teaching objective, and motivate the students; (b) create conducive atmosphere in presenting prerequisite materials and in discussing structured tasks; (c) provide and manage relevant learning resources that support the learning process; (d) understand the students' condition in terms of quitter, camper, and climber category; (e) guide students in group discussion, group presentation, and in summarizing; and (g) facilitate assignment for students individually and in group.

Supporting system is needed in order that the teaching and learning activities run effectively and efficiently. The supporting system of PMBAQAP model covers: (a) the lesson plans are designed student-centered, the lecturer's references, students' book, students worksheets contain geometry teaching problems, the media are of geometry. 
PMBAQAP model has instructional effect and nurturants. The expected instructional effect is the increase of students' achievement in the course of Geometry Teaching. While the nurturants are the increase of students AQ, student's learning independency, the student's learning activeness, and student's positive attitude toward mathematics. PMBAQAP model can change the student's negative attitude into positive attitude toward mathematics.

Other products in the stage of designing and realization/construction are instruments of product evaluation covering: (a) model evaluation sheet, (b) observation sheet of the model implementation, (c) observation sheet of teaching management, (d) observation sheet of lecturer's activities, (e) observation sheet of student's activities, (f) questionnaire of lecturer's response about the implementation of PMBAQAP model, (g) questionnaire of student's response about the implementation of PMBAQAP model, and (h) adversity response profile.

\section{CONCLUSION}

Based on the result and discussion, it is concluded that: The components of the PMBAQAP model consist of: syntax, social system, reaction principles, supporting system, and instructional effect as well as it nurturing effect. Syntax of PMBAQAP model consists of: introduction, core, and closing. The activities in introduction phase cover: (a) opening the lesson, (b) greeting and praying, (c) attendance check, (d) introducing learning objectives, (e) motivating, (f) informing prerequisite materials, (g) discussing structured tasks, (h) grouping students based on their AQ categories. The activities in core phase cover: (a) the distribution of worksheets, (e) group discussion, (f) group presentation, (g) conclusion of discussion, (h) evaluation, and (i). The activity in closing phase assigning structured tasks individually and in groups. Prominent social system in PMBAQAP model is the lecturer's role as advisor and facilitator in giving information and directing students in discussion and conclusion. Reaction principle in form of lecturer's behaviors expected to establish in implementing PMBAQAP model are: (a) create conducive atmosphere in introducing the teaching objective, and motivate the students; (b) create conducive atmosphere in presenting prerequisite materials and in discussing structured tasks; (c) provide and manage relevant learning resources that support the learning process; (d) understand the students' condition in terms of quitter, camper, and climber category; (e) guide students in group discussion, group presentation, and in summarizing; and (g) facilitate assignment for students individually and in group. The supporting system of PMBAQAP model covers: (a) the lesson plans are designed student-centered, the lecturer's references, students' book, students worksheets contain geometry teaching problems, the media are of. The instructional effect of PMBAQAP model is the increase of students' achievement in the course of Geometry Teaching, and the nurturants are the increase of students AQ, student's learning independency, the student's learning activeness, and student's positive attitude toward mathematics

\section{REFERENCES}

Akpan, J. P., \& Beard, L. A. (2016). Using constructivist teaching strategies to enhance academic outcomes of students with special needs. Universal Journal of Educational Research, 4(2), 392-398.

Bautista, M. J. C. (2015). Adversity quotient and teaching performance of faculty members. International Journal of Scientific and Research Publications, 5(3), 1-6. 
Bennu, S. (2011). Proses berpikir siswa quitter pada sekolah menengah pertama dalam menyelesaikan masalah matematika. Edumatica, 1(2), 15-24.

Bennu, S. (2012). Adversity quotient: Kajian kemungkinan pengintegrasiannya dalam pembelajaran matematika. Aksioma, 1(1), 56-62.

Bennu, S. (2015). Proses berpikir siswa climber pada Kelas VII sekolah menengah pertama dalam menyelesaikan masalah matematika. Jurnal Pendidikan Matematika dan Terapan, $1(3), 52-64$.

Boa, E. A., Wattanatorn, A., \& Tagong, K. (2018). The development and validation of the Blended Socratic Method of Teaching (BSMT): An instructional model to enhance critical thinking skills of undergraduate business students. Kasetsart Journal of Social Sciences, 39(1), 81-89.

Blackmore, C. (2010). Social learning systems and communities of practice (pp. 44-50). London: Springer.

Cando, J. M. D., \& Villacastin, L. N. (2014). The relationship between adversity quotient (AQ) and emotional quotient (EQ) and teaching performance of college PE faculty members of CIT University. International Journal of Sciences: Basic and Applied Research, 18(2), 354-357.

D'sousa, R. (2006). A study of adversity quotient of secondary school students in relation to their school performace and the school climate. Departement of Education University of Mumbay.

Gidena, A., \& Gebeyehu, D. (2017). The effectiveness of advance organiser model on students' academic achievement in learning work and energy. International Journal of Science Education, 39(16), 2226-2242.

Hema, G., \& Gupta, M. (2015). Adversity quotient for prospective higher education. The International Journal of Indian Psychology, 4, 49-64.

Joyce, B., Weil, M., \& Calhoun, E. (2009). Models of teaching (Eighth Edition). Boston: Allyn and Bacon.

Kamboj, S., Sarmah, B., Gupta, S., \& Dwivedi, Y. (2018). Examining branding co-creation in brand communities on social media: Applying the paradigm of Stimulus-OrganismResponse. International Journal of Information Management, 39, 169-185.

Kristanti, F., Ainy, C., Shoffa, S., Khabibah, S., \& Amin, S. M. (2018). Developing creativeproblem-solving-based student worksheets for transformation geometry course. International Journal on Teaching and Learning Mathematics, 1(1), 13-23.

Kroll, L. R., \& Laboskey, V. K. (1996). Practicing what we preach: Constructivism in a teacher education program. Action in teacher education, 18(2), 63-72.

Marashi, H., \& Rashidian, S. (2018). EFL teachers' adversity quotient, personal growth initiative, and pedagogical success. Journal of Teaching Language Skills, 37(3), 93-139.

Noorloos, R., Taylor, S. D., Bakker, A., \& Derry, J. (2017). Inferentialism as an alternative to socioconstructivism in mathematics education. Mathematics Education Research Journal, 29(4), 437-453.

Parvathy, U., \& Praseeda, M. (2014). Relationship between adversity quotient and academic problems among student teachers. Journal of Humanities and Social Science, 19(11), 2326.

Pea, R. D. (2004). The social and technological dimensions of scaffolding and related theoretical concepts for learning, education, and human activity. The journal of the learning sciences, 13(3), 423-451. 
Plomp, T. (1997). Educational and training system design. Univercity of Twente.

Santos, M. C. J. (2012). Assessing the effectiveness of the adapted adversity quotient program in a special education school. Researchers World, 3(4), 13-23.

Stoltz, P. G. (1997). Adversity quotient: Turning obstacles into opportunities. John Wiley \& Sons.

Stoltz, P. G. (2000). Adversity quotient: Turning obstacles into opportunities (Mengubah hambatan menjadi peluang). PT. Gramedia Widiasarana Indonesia.

Vrasidas, C. (2000). Constructivism versus objectivism: Implications for interaction, course design, and evaluation in distance education. International journal of educational telecommunications, 6(4), 339-362.

Wenger, E. (2010). Communities of practice and social learning systems: the career of a concept. In Social learning systems and communities of practice (pp. 179-198). Springer, London.

Wheatley, G. H. (1991). Constructivist perspectives on science and mathematics learning. Science Education, 75(1), 9-21.

Yani, M., Ikhsan, M., \& Marwan, M. (2016). Proses berpikir siswa sekolah menengah pertama dalam memecahkan masalah matematika berdasarkan langkah-langkah Polya ditinjau dari adversity quotient. Jurnal Pendidikan Matematika, 10(1), 43-57. 